\title{
35. PETROLOGY OF (ALPINE-TYPE) PERIDOTITES FROM SITE 395, DSDP LEG 45
}

\author{
John M. Sinton, ${ }^{1}$ Department of Mineral Sciences, Smithsonian Institution, Washington, D.C.
}

\begin{abstract}
Two moderately altered peridotite horizons occur with brecciated contacts between 159 and 169 meters sub-bottom at Site 395 . Both sampled horizons were originally four-phase peridotites (olivine $>_{\text {opx }} \gg$ cpx $\geqslant$ spinel) with foliated metamorphic tectonite textures; irregular spinel grains locally contain silicate inclusions. Mineral compositions are nearly constant in both horizons; olivine $\mathrm{Mg} /(\mathrm{Mg}+\mathrm{Fe})$ ratios range from 0.900 to 0.911 . Pyroxenes have notably low $\mathrm{Na}$ and $\mathrm{Ti}$ contents and spinels have $\mathrm{Cr} /(\mathrm{Cr}+\mathrm{Al}+$ $\mathrm{Fe}^{3+}$ ) values in the range $0.349-0.394$ with low $\mathrm{Ti}$ and $\mathrm{Fe}^{3+}$. These characteristics are similar to those of pyroxenes and spinels in alpine-type peridotites. Mineral cores give calculated equilibration temperatures of $1060^{\circ}-1080^{\circ} \mathrm{C}$. Compositional rims on pyroxenes and spinels indicate a lower temperature partial re-equilibration and give calculated equilibration temperatures of $1040^{\circ}-1050^{\circ} \mathrm{C}$. The combination of tectonite textures, depleted mineral compositions, and the possible interpretation of the mineral rims as evidence for a partial fusion event in the history of the peridotites, provides the basis for concluding that these rocks are residual in origin. The relatively shallow occurrence of what probably represents upper mantle material indicates a complex structure for Layer 2 in this region.
\end{abstract}

\section{INTRODUCTION}

Hole 395 (DSDP Site 395) was a single-bit hole, drilled in 4484 meters of water. At this site, two horizons of peridotite occur between 159 and 169 meters (sub-bottom). An upper harzburgitic peridotite horizon is separated from overlying aphyric basalt by a carbonate-cemented serpentinite breccia; the actual contacts were not recovered. The harzburgite section consists of 1.4 meters of continuously recovered harzburgite with a tectonic foliation well developed at $40^{\circ}$ to the vertical. This section is separated from a 1 -meter serpentinized lherzolite by another carbonate-cemented serpentinite breccia that includes what may be a basaltic dike. The lherzolite overlies a further breccia zone which in turn overlies plagioclase-olivine phyric pillow basalts.

Samples from each of the two peridotite zones have been studied with the objective of relating these rocks to the enclosing basalts at Site 395 and to sub-sea floor processes. Peridotite samples were not recovered from Hole $395 \mathrm{~A}$ at the same site (about 60 feet away), and it is clear that these samples reflect a very localized occurrence. The carbonate-cemented breccia contacts strongly suggest cold tectonic emplacement of the peridotites into Layer 2 of this area.

${ }^{1}$ Present address: Hawaii Institute of Geophysics, University of Hawaii, Honolulu, Hawaii.

\section{PETROGRAPHY}

Both peridotite samples available for study were originally four-phase (olivine $>$ orthopyroxene $\gg$ clinopyroxene $\geqslant$ spinel) peridotites which have now been variably altered to serpentine + opaque iron oxides. Plagioclase and its alteration products are notably absent. Harzburgite Sample 395-18-1, 56-64cm has well-developed foliation defined mainly by elongation of pyroxene augen up to $15 \mathrm{~mm}$ across in a recrystallized olivine-pyroxene-spinel matrix. The rock is about 35 to 40 per cent alteration minerals (serpentine + opaques), and except for large orthopyroxene augen, olivine and pyroxene grains average about 4 to $5 \mathrm{~mm}$. Olivine is typically kink-banded and interstitial. Olivine between pyroxene grains makes up a recrystallized mosaic; $120^{\circ}$ grain boundary intersection angles are common. Clinopyroxene does not occur as augen but is present as interstitial grains up to 3 to $4 \mathrm{~mm}$ across. Both ortho- and clinopyroxene contain exsolution lamellae; the coarser blebs (up to $60 \mu \mathrm{m}$ ) occur in the former. Spinel has highly irregular form, is generally less than $1 \mathrm{~mm}$ in maximum size, and in thin section is translucent red, commonly with opaque overgrowths. Opaque overgrowths on translucent spinels and trails of opaque grains associated with serpentine veins probably formed during alteration processes. Spinel locally encloses rounded silicates with a micropoikiloblastic texture.

Lherzolite Sample $395-18-2,127-136 \mathrm{~cm}$ originally contained a greater proportion of spinel and clinopy- 
roxene than did Sample $395-18-1,56-64 \mathrm{~cm}$, but is now 60 to 65 per cent altered (Table 1). Clinopyroxene in the lherzolite locally forms augen up to 5 to $6 \mathrm{~mm}$ across, with coarse (up to $150 \mu \mathrm{m}$ ) exsolved blebs of orthopyroxene. All silicates are locally kink-banded. Spinel habit varies from subhedral to highly irregular, and grains up to $3 \mathrm{~mm}$ across are common. The lherzolite sample is not as well foliated as the harzburgite, but a recrystallized texture is prominent in thin section and a crude foliation defined by trains of spinel and pyroxene is locally apparent (Figure 1).

Estimated pre-serpentinization modes, based on examination of several thin sections of each of the two sampled intervals, are given in Table 1.

TABLE 1

Estimated Modal Contents (vol \%) of Analyzed Site 395 Peridotites

\begin{tabular}{lcc}
\hline & $\begin{array}{c}\text { Harzburgite } \\
\text { Sample 18-1, } \\
56-64 \mathrm{~cm}\end{array}$ & $\begin{array}{c}\text { Lherzolite } \\
\text { Sample 18-2, } \\
127-136 \mathrm{~cm}\end{array}$ \\
\cline { 2 - 3 } Olivine & $60-65$ & $55-60$ \\
Orthopyroxene & 35 & 30 \\
Clinopyroxene & $2-4$ & $8-12$ \\
Spinel & $1-2$ & $4-5$ \\
$\begin{array}{l}\text { Present proportion of } \\
\text { alteration minerals }\end{array}$ & $35-40$ & $60-65$ \\
\hline
\end{tabular}

\section{MINERAL CHEMISTRY}

Mineral compositions reported here were obtained with a 9-channel ARL SEMQ microprobe at the National Museum of Natural History, Washington, D.C., using an accelerating voltage of $15 \mathrm{kv}$, beam current of $0.15-0.20 \mu \mathrm{A}$, and a 1-3 $\mu \mathrm{m}$ beam diameter. At least five countings of 10 -second integration time were standardized against a combination of natural and synthetic standards and averaged for each analysis. Data correction was according to the method of Bence and Albee (1968). Reported analyses are from several sections of each of the sampled intervals.

Analysed olivine grains are homogeneous, and rims are compositionally identical to cores. However, pyroxenes and spinels have 5-80 $\mu \mathrm{m}$ rims which are compositionally distinct from the cores of these minerals.

\section{Olivine}

Olivine (Fo 90) in the harzburgite (Sample 395-18$1,56-64 \mathrm{~cm})$ is slightly $(0.6-1.1 \mathrm{~mol} \% \mathrm{Fo})$ less Mg-rich than that in the lherzolite Sample 395-18-2, 127-136cm (Table 2). Ca and Mn values are uniformly low, and $\mathrm{Ni}$ contents in both sampled horizons are constant at about 0.4 wt per cent. The relatively high $\mathrm{Mg} /(\mathrm{Mg}+$ $\mathrm{Fe}$ ) and $\mathrm{NiO}$ contents of Hole 395 peridotitic olivines are typical of those in alpine peridotites and in peridotite inclusions in basalts. Olivines in the ultramafic zones of stratiform intrusions are also locally more magnesian than $\mathrm{Fo}_{90}$, but generally show a range extending to more Fe-rich compositions (e.g., Jackson, 1969).

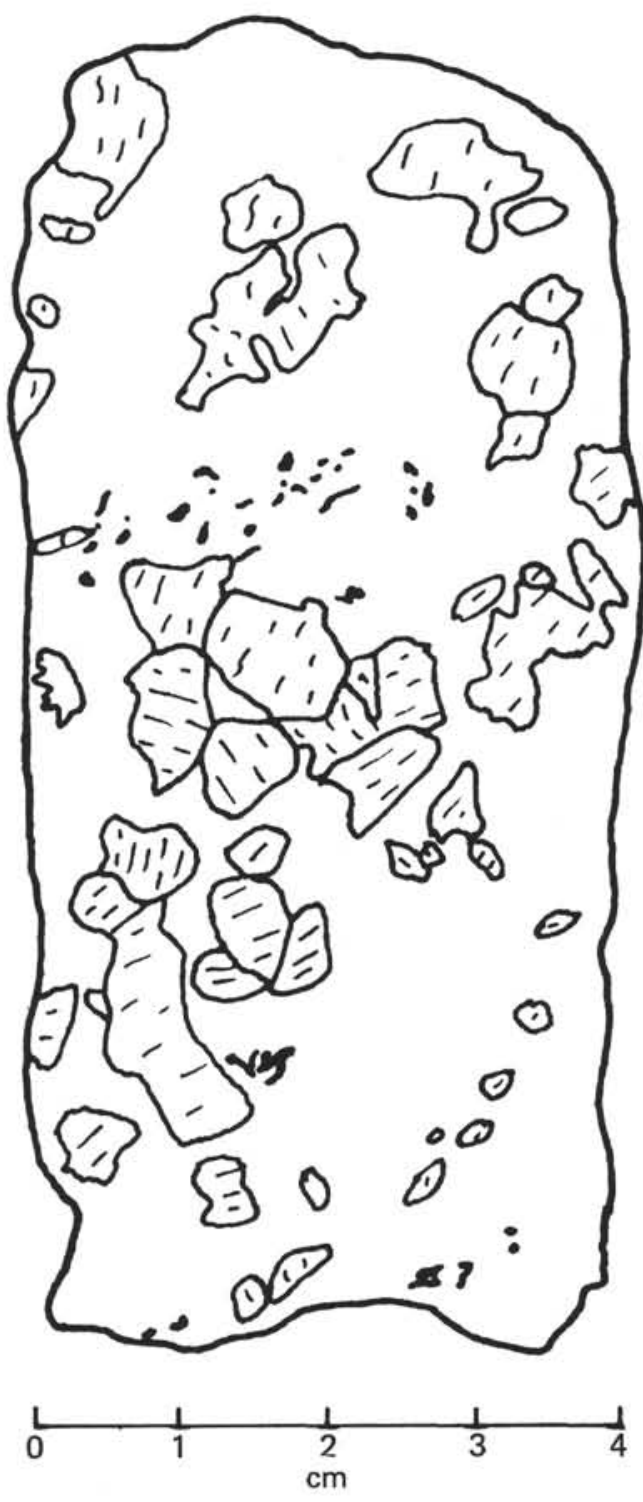

Figure 1. Sketch of a sawed surface of lherzolite Sample 395-18-2, 127-136 cm. Irregular black grains are chrome-spinel; larger cleaved minerals are pyroxenes; unpatterned areas are mainly olivine + serpentine. Note the crude foliation running $S W-N E$ across the figure.

\section{Pyroxene}

$\mathrm{Mg} /(\mathrm{Mg}+\mathrm{Fe})$ contents of orthopyroxene cores from both sampled intervals are constant at 0.900 \pm 0.003 , but are more variable in orthopyroxene rims and in exsolved grains (Table 3 ). $\mathrm{Ti}, \mathrm{Na}$, and $\mathrm{K}$ contents are uniformly very low. $\mathrm{Cr}_{2} \mathrm{O}_{3} / \mathrm{Al}_{2} \mathrm{O}_{3}$ is nearly constant in orthopyroxene cores $(\cong 0.286)$ and rims

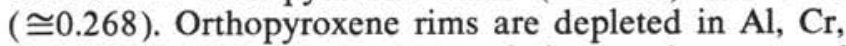
and $\mathrm{Ca} /(\mathrm{Ca}+\mathrm{Mg}+\mathrm{Fe})$, relative to the cores of analyzed grains.

Clinopyroxene $\mathrm{Mg} /(\mathrm{Mg}+\mathrm{Fe})$ is relatively constant in the range $0.913 \pm 0.006$ (Table 4), and $\mathrm{Na}, \mathrm{Ti}$, and $\mathrm{K}$ values are all low. There is a crude correlation of 
TABLE 2

Selected Microprobe Analyses of Olivine From Leg 45, Site 395 Peridotites

\begin{tabular}{|c|c|c|c|c|c|c|c|c|c|}
\hline \multirow[b]{2}{*}{$\mathrm{SiO}_{2}$} & \multicolumn{3}{|c|}{ Sample $18-1,56-64 \mathrm{~cm}$} & \multicolumn{6}{|c|}{ Sample $18-2,127-136 \mathrm{~cm}$} \\
\hline & 40.2 & 40.5 & 40.6 & 40.4 & 40.9 & 40.7 & 40.6 & 40.1 & 40.2 \\
\hline $\mathrm{FeO}^{*}$ & 9.55 & 9.57 & 9.81 & 8.82 & 8.74 & 9.03 & 9.17 & 9.11 & 9.14 \\
\hline $\mathrm{MnO}$ & 0.12 & 0.12 & 0.12 & 0.11 & 0.13 & 0.12 & 0.11 & 0.11 & 0.13 \\
\hline $\mathrm{MgO}$ & 49.9 & 49.4 & 49.7 & 50.2 & 50.2 & 50.1 & 49.3 & 49.6 & 49.9 \\
\hline $\mathrm{CaO}$ & 0.05 & 0.09 & 0.08 & 0.04 & 0.04 & 0.02 & 0.10 & 0.07 & 0.05 \\
\hline $\mathrm{NiO}$ & 0.38 & 0.40 & 0.42 & 0.37 & 0.38 & 0.40 & 0.40 & 0.37 & 0.37 \\
\hline Total & 100.2 & 100.1 & 100.7 & 99.9 & 100.4 & 100.4 & 99.7 & 99.4 & 99.8 \\
\hline \multicolumn{10}{|c|}{ Cations on the Basis of 4 Oxygens } \\
\hline $\mathrm{Si}$ & 0.985 & 0.993 & 0.990 & 0.989 & 0.995 & 0.992 & 0.997 & 0.989 & 0.987 \\
\hline $\mathrm{Fe}$ & 0.196 & 0.196 & 0.200 & 0.181 & 0.178 & 0.184 & 0.118 & 0.188 & 0.188 \\
\hline $\mathrm{Mn}$ & 0.002 & 0.002 & 0.002 & 0.002 & 0.003 & 0.002 & 0.002 & 0.002 & 0.003 \\
\hline $\mathrm{Mg}$ & 1.823 & 1.805 & 1.807 & 1.831 & 1.820 & 1.820 & 1.805 & 1.823 & 1.826 \\
\hline $\mathrm{Ca}$ & 0.001 & 0.002 & 0.002 & 0.001 & 0.001 & 0.001 & 0.003 & 0.002 & 0.001 \\
\hline $\mathrm{Ni}$ & 0.007 & 0.008 & 0.008 & 0.007 & 0.007 & 0.008 & 0.008 & 0.007 & 0.007 \\
\hline $\begin{array}{l}\text { Total } \\
\text { mol. } \%\end{array}$ & 3.014 & 3.006 & 3.009 & 3.011 & 3.004 & 3.007 & 3.003 & 3.011 & 3.012 \\
\hline Fo & 90.3 & 90.2 & 90.0 & 91.0 & 91.1 & 90.8 & 90.6 & 90.7 & 90.7 \\
\hline
\end{tabular}

TABLE 3

Selected Microprobe Analyses of Orthopyroxene From Leg 45, Site 395 Peridotites

\begin{tabular}{|c|c|c|c|c|c|c|c|c|c|}
\hline \multicolumn{6}{|c|}{ Sample $18-1,56-64 \mathrm{~cm}$} & \multicolumn{4}{|c|}{ Sample $18-2,127-136 \mathrm{~cm}$} \\
\hline & $1 \mathrm{a}$ & $1 \mathrm{~b}$ & $2 \mathrm{a}$ & $2 \mathrm{~b}$ & 3 & $4 a$ & $4 \mathrm{~b}$ & $5 \mathrm{a}$ & $5 \mathrm{~b}$ \\
\hline $\mathrm{SiO}_{2}$ & 54.6 & 55.9 & 53.1 & 53.7 & 53.6 & 53.9 & 55.4 & 54.3 & 54.5 \\
\hline $\mathrm{TiO}_{2}$ & 0.06 & 0.06 & 0.09 & 0.08 & 0.06 & 0.07 & 0.08 & 0.09 & 0.07 \\
\hline $\mathrm{Al}_{2} \mathrm{O}_{3}$ & 3.03 & 2.50 & 3.40 & 3.16 & 4.47 & 3.64 & 2.47 & 3.41 & 3.25 \\
\hline $\mathrm{FeO}^{*}$ & 6.56 & 6.77 & 6.57 & 6.64 & 6.92 & 6.46 & 6.11 & 6.16 & 6.21 \\
\hline $\mathrm{MnO}$ & n.d. & n.d. & 0.12 & 0.12 & n.d. & 0.11 & 0.11 & 0.13 & 0.11 \\
\hline $\mathrm{MgO}$ & 33.1 & 33.4 & 32.1 & 33.2 & 32.3 & 32.4 & 33.5 & 31.8 & 32.7 \\
\hline $\mathrm{CaO}$ & 1.59 & 0.94 & 1.86 & 1.28 & 0.90 & 1.16 & 0.89 & 2.36 & 0.92 \\
\hline $\mathrm{Na}_{2} \mathrm{O}$ & 0.01 & 0.01 & 0.01 & 0.01 & 0.02 & 0.00 & 0.00 & 0.01 & 0.01 \\
\hline $\mathrm{K}_{2} \mathrm{O}$ & 0.02 & 0.01 & 0.01 & 0.02 & 0.02 & 0.01 & 0.01 & 0.01 & 0.00 \\
\hline $\mathrm{Cr}_{2} \mathrm{O}_{3}$ & 0.89 & 0.58 & 1.06 & 0.84 & 1.21 & 1.05 & 0.61 & 0.97 & 0.90 \\
\hline Total & 99.9 & 100.2 & 98.3 & 99.1 & 99.5 & 98.8 & 99.2 & 99.2 & 98.7 \\
\hline \multicolumn{10}{|c|}{ Cations on the Basis of 6 Oxygens } \\
\hline $\mathrm{Si}$ & 1.902 & 1.934 & 1.885 & 1.888 & 1.875 & 1.895 & 1.931 & 1.904 & 1.913 \\
\hline $\mathrm{Al}^{\mathrm{IV}}$ & 0.098 & 0.066 & 0.115 & 0.112 & 0.125 & 0.105 & 0.069 & 0.096 & 0.086 \\
\hline $\mathrm{Al} \mathrm{VI}$ & 0.026 & 0.036 & 0.027 & 0.019 & 0.059 & 0.046 & 0.033 & 0.045 & 0.047 \\
\hline $\mathrm{Ti}$ & 0.002 & 0.002 & 0.002 & 0.002 & 0.002 & 0.002 & 0.002 & 0.002 & 0.002 \\
\hline $\mathrm{Fe}$ & 0.191 & 0.196 & 0.195 & 0.195 & 0.202 & 0.190 & 0.178 & 0.181 & 0.182 \\
\hline Mn & - & - & 0.004 & 0.004 & - & 0.003 & 0.003 & 0.004 & 0.003 \\
\hline $\mathrm{Mg}$ & 1.718 & 1.722 & 1.698 & 1.740 & 1.684 & 1.698 & 1.741 & 1.662 & 1.711 \\
\hline $\mathrm{Ca}$ & 0.059 & 0.035 & 0.071 & 0.048 & 0.034 & 0.044 & 0.033 & 0.089 & 0.035 \\
\hline $\mathrm{Na}$ & 0.001 & 0.001 & 0.001 & 0.001 & 0.001 & 0.000 & 0.000 & 0.001 & 0.001 \\
\hline $\mathrm{K}$ & 0.001 & 0.000 & 0.000 & 0.001 & 0.001 & 0.000 & 0.000 & 0.000 & 0.000 \\
\hline $\mathrm{Cr}$ & 0.025 & 0.016 & 0.030 & 0.023 & 0.033 & 0.029 & 0.017 & 0.027 & 0.025 \\
\hline Total & 4.023 & 4.008 & 4.028 & 4.033 & 4.016 & 4.012 & 4.007 & 4.011 & 4.005 \\
\hline $\begin{array}{l}100 \mathrm{Mg} \\
\mathrm{Mg}+\mathrm{Fe}\end{array}$ & 90.0 & 89.8 & 89.7 & 89.9 & 89.3 & 89.9 & 90.7 & 90.2 & 90.4 \\
\hline $\begin{array}{c}100 \mathrm{Ca} \\
\mathrm{Ca}+\mathrm{Mg}+\mathrm{Fe}\end{array}$ & 3.0 & 1.8 & 3.6 & 2.4 & 1.8 & 2.3 & 1.7 & 4.6 & 1.8 \\
\hline
\end{tabular}

Note: $*=$ total $\mathrm{Fe}$ as $\mathrm{FeO} ; \mathrm{n} . \mathrm{d} .=$ not determined; $\mathrm{a}=\mathrm{opx}$ core $\mathrm{b}=$ same opx rim; anal. $3=$ opx exsolved from cpx host (anal. 2, Table 4).

$\mathrm{Cr}_{2} \mathrm{O}_{3}$ with $\mathrm{Al}_{2} \mathrm{O}_{3}$, but $\mathrm{Cr}_{2} \mathrm{O}_{3} / \mathrm{Al}_{2} \mathrm{O}_{3}$ in clinopyroxene is generally greater than that of coexisting orthopyroxene. Clinopyroxene rims are depleted in $\mathrm{Al}$ and $\mathrm{Cr}$, and generally show an increase in $\mathrm{Mg} /(\mathrm{Mg}+\mathrm{Fe})$ and $\mathrm{Ca} /$ $(\mathrm{Ca}+\mathrm{Mg}+\mathrm{Fe})$ relative to the associated cores.

Since all the pyroxenes analyzed in this study are decidedly low in $\mathrm{Na}$ and $\mathrm{Ti}, \mathrm{Al}$ can be assumed to be present as Tschermak component $\left(\mathrm{R}^{2+} \mathrm{Al}_{2} \mathrm{SiO}_{6}\right)$, and the decrease in $\mathrm{Al}$ in both ortho- and clinopyroxene rims therefore indicates a decrease in the solubility of Tschermak component in the host pyroxenes. Since $\mathrm{Mg} /(\mathrm{Mg}+\mathrm{Fe})$ is greater in clinopyroxene than in orthopyroxene, the increase in $\mathrm{Mg} / \mathrm{Fe}$ in clinopyroxene rims probably indicates a decrease in the solubility of OPX $\left[\left(\mathrm{MgFe}_{2} \mathrm{Si}_{2} \mathrm{O}_{6}\right)\right]$ component in the rims relative to the cores. Similarly, the decrease in $\mathrm{Ca} /(\mathrm{Ca}+\mathrm{Mg}$ 
TABLE 4

Selected Microprobe Analyses of Clinopyroxenes From Leg 45, Site 395 Peridotites

\begin{tabular}{|c|c|c|c|c|c|c|c|c|}
\hline & \multicolumn{2}{|c|}{$\begin{array}{c}\text { Sample } \\
18-1,56-64 \mathrm{~cm}\end{array}$} & \multicolumn{6}{|c|}{ Sample $18-2,127-136 \mathrm{~cm}$} \\
\hline & $1 \mathrm{a}$ & $1 \mathrm{~b}$ & $2 \mathrm{a}$ & $2 \mathrm{~b}$ & $3 \mathrm{a}$ & $3 b$ & 4 & 5 \\
\hline $\mathrm{SiO}_{2}$ & 51.7 & 52.4 & 51.0 & 51.2 & 50.1 & 50.5 & 51.5 & 51.4 \\
\hline $\mathrm{TiO}_{2}$ & 0.13 & 0.11 & 0.12 & 0.13 & 0.18 & 0.13 & 0.12 & 0.14 \\
\hline $\mathrm{Al}_{2} \mathrm{O}_{3}$ & 4.35 & 3.55 & 4.86 & 4.64 & 4.83 & 4.15 & 4.54 & 4.67 \\
\hline $\mathrm{FeO} *$ & 2.73 & 2.63 & 2.74 & 2.53 & 3.08 & 2.70 & 2.66 & 2.55 \\
\hline $\mathrm{MnO}$ & 0.10 & 0.10 & 0.10 & 0.10 & n.d. & 0.10 & 0.10 & 0.10 \\
\hline $\mathrm{MgO}$ & 17.0 & 17.2 & 16.6 & 16.5 & 16.6 & 16.9 & 16.9 & 16.5 \\
\hline $\mathrm{CaO}$ & 22.8 & 23.1 & 23.0 & 23.3 & 23.1 & 23.2 & 22.8 & 23.1 \\
\hline $\mathrm{Na}_{2} \mathrm{O}$ & 0.22 & 0.19 & 0.11 & 0.11 & 0.11 & 0.10 & 0.13 & 0.12 \\
\hline $\mathrm{K}_{2} \mathrm{O}$ & 0.02 & 0.02 & 0.01 & 0.00 & 0.03 & 0.01 & 0.01 & 0.02 \\
\hline $\mathrm{Cr}_{2} \mathrm{O}$ & 1.40 & 1.01 & 1.46 & 1.49 & 1.56 & 1.15 & 1.47 & 1.44 \\
\hline Total & 100.5 & 100.3 & 100.0 & 100.0 & 99.6 & 98.9 & 100.2 & 100.0 \\
\hline \multicolumn{9}{|c|}{ Cations on the Basis of 6 Oxygens } \\
\hline $\mathrm{Si}$ & 1.877 & 1.902 & 1.862 & 1.868 & 1.844 & 1.866 & 1.873 & 1.873 \\
\hline $\mathrm{Al} I \mathrm{~V}$ & 0.123 & 0.098 & 0.138 & 0.132 & 0.156 & 0.134 & 0.127 & 0.127 \\
\hline $\mathrm{Al}^{\mathrm{VI}}$ & 0.063 & 0.054 & 0.071 & 0.068 & 0.053 & 0.047 & 0.068 & 0.074 \\
\hline $\mathrm{Ti}$ & 0.004 & 0.003 & 0.003 & 0.004 & 0.005 & 0.004 & 0.003 & 0.004 \\
\hline $\mathrm{Fe}$ & 0.083 & 0.080 & 0.084 & 0.077 & 0.095 & 0.083 & 0.081 & 0.078 \\
\hline $\mathrm{Mn}$ & 0.003 & 0.003 & 0.003 & 0.003 & - & 0.003 & 0.003 & 0.003 \\
\hline $\mathrm{Mg}$ & 0.920 & 0.930 & 0.903 & 0.897 & 0.910 & 0.931 & 0.916 & 0.896 \\
\hline $\mathrm{Ca}$ & 0.887 & 0.898 & 0.900 & 0.911 & 0.911 & 0.918 & 0.888 & 0.902 \\
\hline $\mathrm{Na}$ & 0.015 & 0.013 & 0.008 & 0.008 & 0.008 & 0.007 & 0.009 & 0.008 \\
\hline $\mathrm{K}$ & 0.001 & 0.001 & 0.000 & 0.000 & 0.001 & 0.000 & 0.000 & 0.001 \\
\hline $\mathrm{Cr}$ & 0.040 & 0.029 & 0.042 & 0.043 & 0.045 & 0.034 & 0.042 & 0.041 \\
\hline Total & 4.016 & 4.011 & 4.014 & 4.011 & 4.028 & 4.027 & 4.010 & 4.007 \\
\hline $\begin{array}{l}100 \mathrm{Mg} \\
\mathrm{Mg}+\mathrm{Fe}\end{array}$ & 91.7 & 92.1 & 91.5 & 92.1 & 90.5 & 91.8 & 91.9 & 92.0 \\
\hline $\begin{array}{c}100 \mathrm{Ca} \\
\mathrm{Ca}+\mathrm{Mg}+\mathrm{Fe}\end{array}$ & 46.9 & 47.1 & 47.7 & 48.3 & 47.5 & 47.5 & 47.1 & 48.1 \\
\hline
\end{tabular}

Note: ${ }^{*}=$ total $\mathrm{Fe}$ as $\mathrm{FeO}$; n.d. = not determined; $\mathrm{a}=\mathrm{cpx}$ core; $\mathrm{b}=$ same cpx rim; anal. $4=$ exsolved cpx in opx host; anal. $5=$ exsolved cpx in opx host (anal. 4, Table 3 ).

$+\mathrm{Fe})$ in orthopyroxene rims probably indicates decreased solubility of $\mathrm{Ca}$-rich pyroxene. At constant temperature, the solubility of enstatite in diopside increases with a decrease in the Ca-Tschermak ( $\mathrm{CaAl}-$ ${ }_{2} \mathrm{SiO}_{6}$ ) component (Boyd, 1970). Although both CaTs and En become slightly less soluble in diopside with increasing pressure, they decrease significantly with falling temperature (Herzberg and Chapman, 1976). The narrow pyroxene rims can therefore be accounted for by lower temperature partial re-equilibration effects, namely exsolution of CaTs and OPX components in clinopyroxene and mainly CaTs component in orthopyroxene. This relationship is similar to that for pyroxenes in the Red Mountain, New Zealand alpinetype peridotite (Sinton, 1977).

\section{Spinel}

Analyzed spinel cores from the sampled intervals occupy a fairly restricted compositional field, with $\mathrm{Cr}$ / $\left(\mathrm{Cr}+\mathrm{Al}+\mathrm{Fe}^{3+}\right)$ from $0.370-0.394$ and $\mathrm{Mg} /(\mathrm{Mg}+$ $\mathrm{Fe}^{2+}$ ) from 0.650-0.670 (Table 5, Figure 2). Although most spinel grains have opaque alteration rims, many have earlier compositional rims, 5-50 $\mu \mathrm{m}$ wide, which have not been obliterated by low-temperature reactions. These rims extend to more $\mathrm{Al}$-rich and $\mathrm{Mg}$-poor compositions than the cores (Figure 2); individual rims are enriched in $\mathrm{Al}$ relative to the associated cores (Table 5). All analyzed spinels are notably depleted in $\mathrm{Ti}$ and $\mathrm{Fe}^{3+}$, and have compositions typical of spinels in alpine peridotites (Figure 3 ). These values are lower than those from stratiform intrusions (cf. Jackson, 1969; Dickey, 1975), including those from Leg 37 plutonic rocks (cf. Hodges and Papike, 1976).

Dickey and Yoder (1972) demonstrated that chromite in equilibrium with clinopyroxene and liquid becomes more chromium-rich with increasing temperature. The decrease in $\mathrm{Cr} / \mathrm{Al}$ in rims compared to cores of Leg 45 spinels therefore probably reflects a lower temperature approach to equilibration for the spinel rims.

\section{GEOTHERMOMETRY}

The pyroxene and spinel core-rim compositional relationships indicate that, neglecting effects of pressure, the rims probably represent adjustments to lower temperature conditions relative to those of the cores. This conclusion is supported by pyroxene equilibration temperatures calculated by the method of Wood and Banno (1973) (Table 6). Although equilibrium partitioning has not been demonstrated for these rocks, such results support the above conclusion of lower relative temperature formation for the mineral rims. 
TABLE 5

Selected Microprobe Analyses of Spinel From Leg 45, Site 395 Peridotites

\begin{tabular}{|c|c|c|c|c|c|c|c|c|c|c|}
\hline & \multicolumn{3}{|c|}{ Sample $18-1,56-64 \mathrm{~cm}$} & \multicolumn{7}{|c|}{ Sample $18-2,127-136 \mathrm{~cm}$} \\
\hline & 1a & $1 b$ & 2 & $3 a$ & $3 b$ & $4 a$ & $4 b$ & $5 \mathrm{a}$ & $5 \mathrm{~b}$ & 6 \\
\hline $\mathrm{TiO}_{2}$ & 0.16 & 0.14 & 0.12 & 0.16 & 0.15 & 0.13 & 0.12 & 0.14 & 0.14 & 0.16 \\
\hline $\mathrm{Cr}_{2} \mathrm{O}_{3}$ & 33.9 & 32.2 & 30.8 & 32.9 & 31.6 & 32.7 & 31.2 & 33.8 & 32.4 & 33.7 \\
\hline $\mathrm{Al}_{2} \mathrm{O}_{3}$ & 33.6 & 35.6 & 37.6 & 35.1 & 36.7 & 35.1 & 32.0 & 34.1 & 34.6 & 33.6 \\
\hline $\mathrm{Fe}_{2} \mathrm{O}_{3}$ & 2.22 & 1.68 & 1.51 & 2.77 & 1.92 & 2.94 & 2.43 & 2.89 & 3.16 & 3.34 \\
\hline $\mathrm{FeO}$ & 14.0 & 15.3 & 14.6 & 14.3 & 14.4 & 13.7 & 15.1 & 13.8 & 14.4 & 13.5 \\
\hline $\mathrm{MnO}$ & 0.28 & 0.30 & 0.21 & 0.25 & 0.27 & 0.28 & 0.27 & 0.30 & 0.27 & 0.27 \\
\hline $\mathrm{MgO}$ & 15.0 & 14.4 & 15.2 & 15.3 & 15.3 & 15.6 & 14.6 & 15.4 & 15.0 & 15.5 \\
\hline Total & 99.1 & 99.7 & 100.1 & 100.8 & 100.3 & 100.4 & 99.7 & 100.4 & 100.0 & 100.1 \\
\hline \multicolumn{11}{|c|}{ Cations on the Basis of 4 Oxygens } \\
\hline $\mathrm{Ti}$ & 0.004 & 0.003 & 0.003 & 0.003 & 0.003 & 0.003 & 0.003 & 0.003 & 0.003 & 0.003 \\
\hline $\mathrm{Cr}$ & 0.785 & 0.739 & 0.696 & 0.746 & 0.715 & 0.743 & 0.714 & 0.771 & 0.743 & 0.772 \\
\hline Al & 1.159 & 1.218 & 1.266 & 1.187 & 1.237 & 1.188 & 1.228 & 1.160 & 1.182 & 1.148 \\
\hline $\mathrm{Fe}^{3+}$ & 0.049 & 0.037 & 0.032 & 0.060 & 0.041 & 0.064 & 0.053 & 0.063 & 0.069 & 0.073 \\
\hline $\mathrm{Fe}^{2+}$ & 0.342 & 0.373 & 0.350 & 0.343 & 0.344 & 0.328 & 0.366 & 0.333 & 0.348 & 0.327 \\
\hline $\mathrm{Mn}$ & 0.007 & 0.007 & 0.005 & 0.006 & 0.007 & 0.007 & 0.007 & 0.007 & 0.007 & 0.007 \\
\hline $\mathrm{Mg}$ & 0.655 & 0.623 & 0.647 & 0.654 & 0.652 & 0.668 & 0.630 & 0.663 & 0.648 & 0.670 \\
\hline $\begin{array}{c}\mathrm{Cr} \\
\mathrm{Cr}+\mathrm{Al}^{+}+\mathrm{Fe}^{3+}\end{array}$ & 0.394 & 0.371 & 0.349 & 0.374 & 0.359 & 0.372 & 0.358 & 0.387 & 0.373 & 0.388 \\
\hline $\begin{array}{c}\mathrm{Mg} \\
\mathrm{Mg}+\mathrm{Fe}^{2+}\end{array}$ & 0.657 & 0.626 & 0.649 & 0.656 & 0.655 & 0.671 & 0.632 & 0.665 & 0.651 & 0.672 \\
\hline
\end{tabular}

Note: $\mathrm{FeO} / \mathrm{Fe}_{2} \mathrm{O}_{3}$ calculated assuming stoichiometric 3 cations per 4 oxygens. $a=$ spinel core; $\mathrm{b}=$ sa me spinel rim.

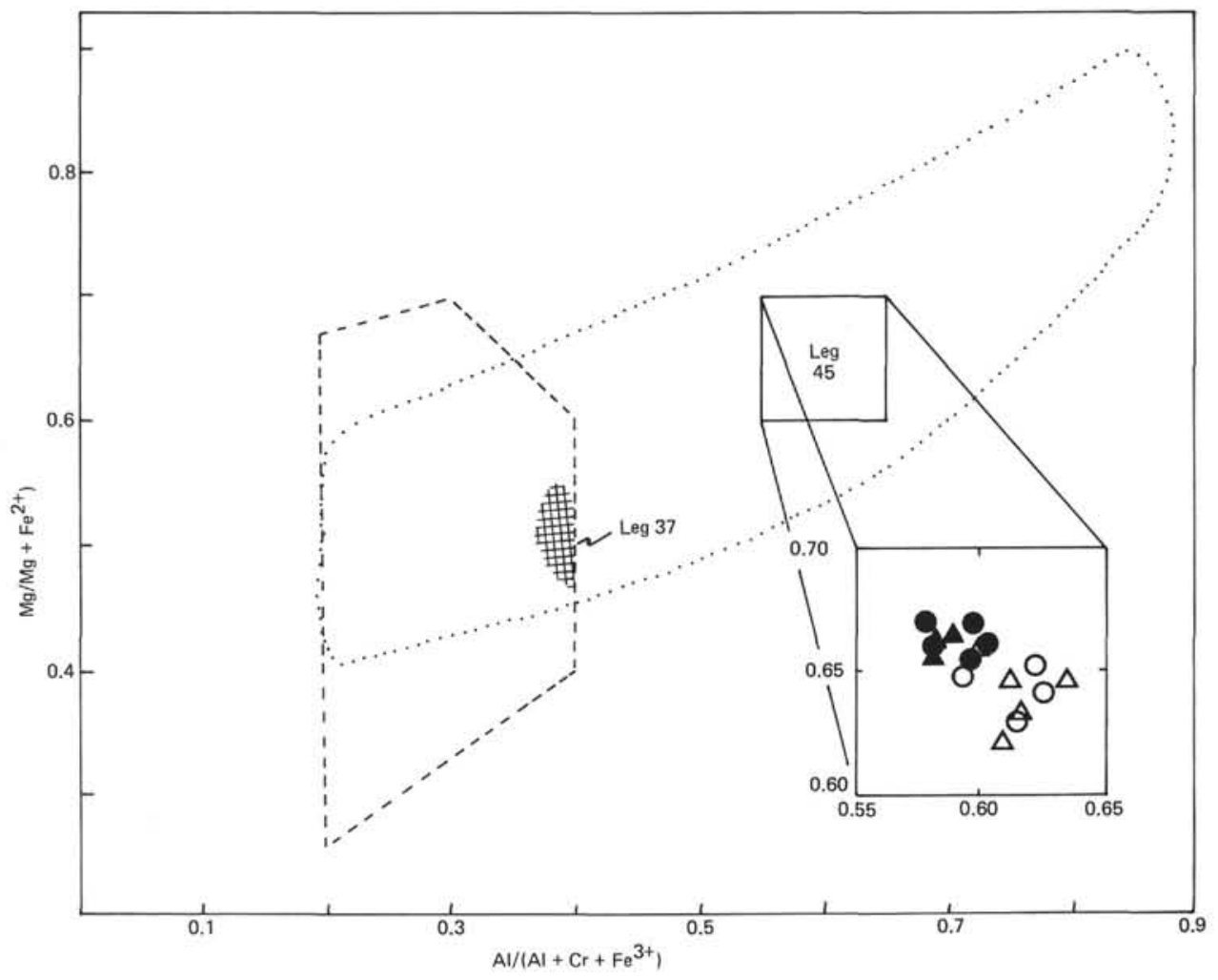

Figure 2. Composition of spinels in Site 395 peridotite Samples 18-2, 56-64 cm (circles) and 18-2, 127-136 cm (triangles) for cores (solid symbols) and rims (open symbols), plotted in terms of their $\mathrm{Mg} /\left(\mathrm{Mg}+\mathrm{Fe}^{2+}\right)$ and $\mathrm{Al} /\left(\mathrm{Al}+\mathrm{Cr}+\mathrm{Fe}^{3+}\right)$ atomic ratios. Dashed line encloses the compositional field of spinels from crustal stratiform intrusions; data for spinels in the Leg 37 plutonic suite are from Hodges and Papike (1976). Dotted line encloses the compositional field of spinels in alpine-type harzburgites and lherzolites. 


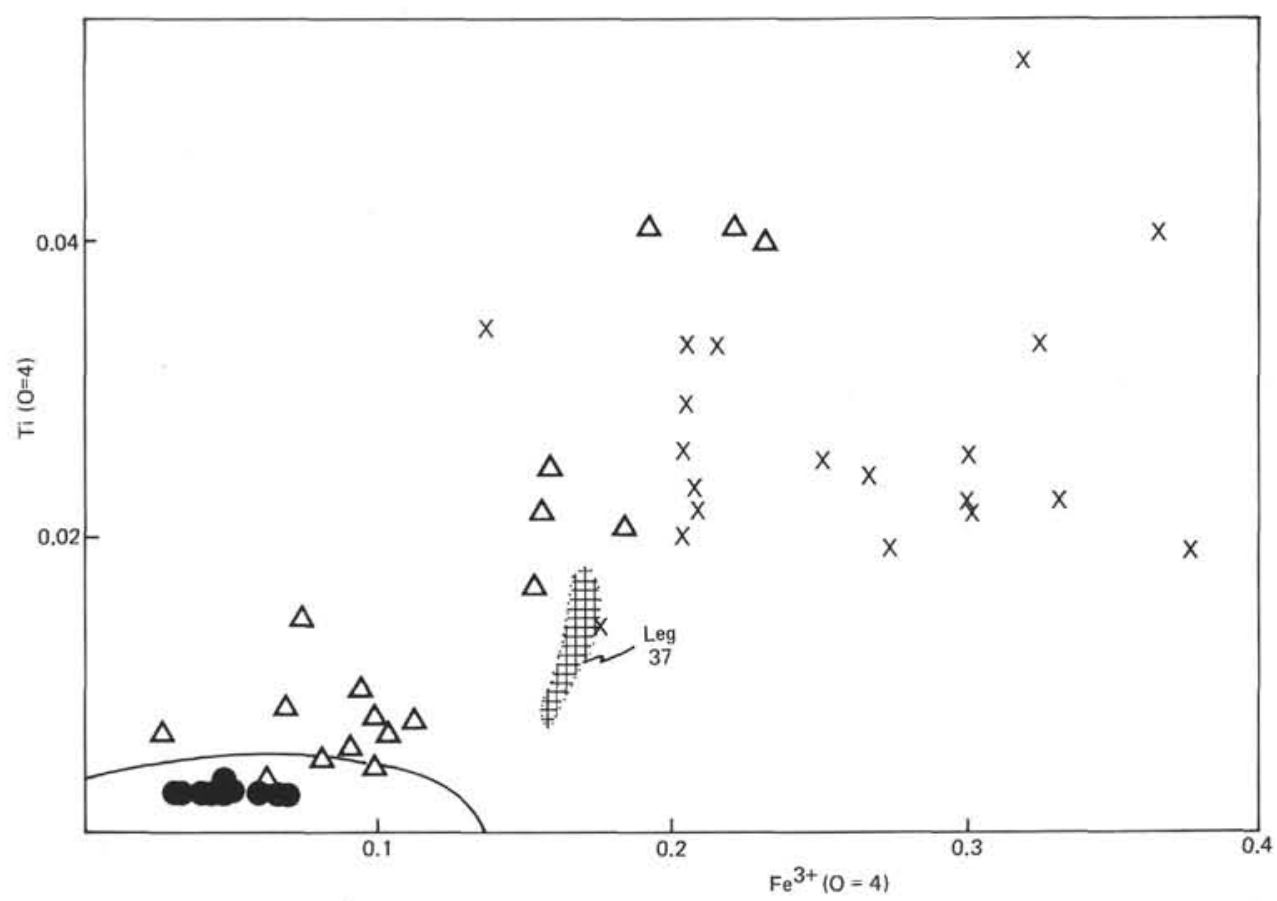

Figure 3. Ti versus $\mathrm{Fe}^{3+}$ cations on the basis of four oxygens per unit formula in spinels in Site 395 peridotite samples (solid circles). Spinels in stratiform intrusions are shown by (x) from the data of Henderson (1975), Wilkinson et al. (1975) and Cameron (1975); liquidus spinels in Mid-Atlantic Ridge basalts (Sigurdsson and Schilling, 1976) and in a submarine basanitoid from near St. Paul's Rocks (unpublished data) are shown by open triangles. Compositional field for spinels in the Leg 37 plutonic suite are from Hodges and Papike (1976). Enclosed field at low Ti contents defines the field of spinels in alpine-type harzburgites after the data of Loney et al. (1971), Himmelberg and Loney (1973), and Sinton (in press). Spinels in some alpine dunites lie outside of this field.

TABLE 6

Calculated Equilibration Temperatures, ${ }^{\circ} \mathrm{C}^{\mathrm{a}}$

\begin{tabular}{lcc}
\hline $\begin{array}{c}\text { Sample } \\
\text { (Interval in cm) }\end{array}$ & Pyroxene Cores & Pyroxene Rims \\
\hline $\begin{array}{l}18-1,56-64 \\
18-2,127-136\end{array}$ & 1080 & 1050 \\
\hline $\begin{array}{l}\text { Temperatures calculated by the method of Wood } \\
\text { and Banno (1973), based on orthopyroxene- } \\
\text { clinopyroxene equilibria. }\end{array}$
\end{tabular}

The effect of pressure on alumina solubility in pyroxene is presently disputable (cf. MacGregor, 1974; Presnall, 1976; Obata, 1976; Wilshire and Jackson, 1975 ), but is apparently minor compared with temperature effects; estimations of equilibration pressures are therefore not attempted in this report.

\section{DISCUSSION}

The textures and mineral compositions of Site 395 peridotites, as well as whole-rock compositions (Bougault, et al., this volume), indicate an origin for these rocks similar to that for alpine peridotites. These rocks generally show recrystallized or strongly tectonized textures; silicates are commonly kink-banded, and spinel is irregular in shape and locally contains inclu- sions of silicates. Such features are incompatible with a magmatic origin, and generally support a metamorphic tectonite history for these rocks. Pyroxenes are notably depleted in $\mathrm{Na}$ and $\mathrm{Ti}$, and spinel is low in $\mathrm{Ti}$ and $\mathrm{Fe}^{3+}$. Olivine has a fairly constant composition in the range Fo 90-91. These mineralogical characteristics are also typical of minerals in alpine peridotites (Loney et al., 1971; Himmelberg and Loney, 1973; Sinton, 1977), and have been cited as evidence for a residual origin of alpine peridotites (Loney et al., 1971; Coombs et al., 1976). The presence of compositional rims on pyroxene and spinel like those in New Zealand alpine peridotite (Sinton, 1977) may similarly indicate re-equilibration of the assemblage with interstitial liquid, and may be direct evidence for partial fusion in the history of these rocks. Such evidence strongly supports the conclusion that Site 395 peridotites have residual compositions, formed by upper mantle partial melting processes.

The nature of the Site 395 peridotites gives further evidence for an alpine assemblage in oceanic crust (e.g., Bonatti et al., 1970), and is consistent with the expected composition for upper mantle (Layer 4) beneath oceanic crust. The apparently tectonic position of these rocks at Site 395 indicates a complex structure in Layer 2 for this region. 


\section{ACKNOWLEDGMENTS}

I am grateful to W. G. Melson for reading an earlier version of this manuscript, and to $C$. R. Obermeyer for instruction and technical assistance in the operation of the microprobe. C. Bell typed the tables and K. Stark typed the final manuscript. The Smithsonian Research Foundation provided financial support during this research.

\section{REFERENCES}

Bence, A. E. and Albee, A. L., 1968. Empirical correction factors for the electron microanalysis of silicates and oxides, J. Geol., v. 76, p. 382-403.

Bonatti, E., Honnorez, J., and Ferrara, G., 1970. Equatorial Mid-Atlantic Ridge: petrologic and $\mathrm{Sr}$ isotope evidence for an alpine-type rock assemblage, Earth Planet. Sci. Lett., v. 9, p. 247-256.

Boyd, F. R., 1970. The system $\mathrm{CaSiO}_{3}-\mathrm{MgSiO}_{3}-\mathrm{Al}_{2} \mathrm{O}_{3}$, Yearbook Carnegie Inst. Wash., v. 68, p. 214-221.

Cameron, E. N., 1975. Postcumulus and subsolidus equilibration of chromite and coexisting silicates in the eastern Bushveld Complex, Geochim. Cosmochim. Acta, v. 39, p. 1021-1033.

Coombs, D. S., Landis, C. A., Norris, R. J., Sinton, J. M., Borns, D. J., and Craw, D., 1976. The Dun Mountain ophiolite belt, New Zealand, its tectonic setting, constitution, and origin, with special reference to the southern portion, Am. J. Sci., v. 276, p. 561-603.

Dickey, J. S., 1975. A hypothesis of origin for podiform chromite deposits, Geochim. Cosmochim. Acta, v. 39, p. 1061-1074.

Dickey, J. S. and Yoder, H. S., Jr., 1972. Partitioning of chromium and aluminum between clinopyroxene and spinel, Yearbook Carnegie Inst. Wash., v. 71, p. 384-392.

Henderson, P., 1975. Reaction trends shown by chromespinels of the Rhum layered intrusion, Geochim. Cosmochim. Acta, v. 39, p. 1035-1044.

Herzberg, C. T. and Chapman, N. A., 1976. Clinopyroxene geothermometry of spinel lherzolites, Am. Mineralogist, v. 61, p. $626-637$.
Himmelberg, G. R. and Loney, R. A., 1973. Petrology of the Vulcan Peak alpine-type peridotite, southwestern Oregon, Geol. Soc. Am. Bull., v. 84, p. 1585-1600.

Hodges, F. N. and Papike, J. J., 1976. Magmatic cumulates from oceanic Layer 3, J. Geophys. Res., v. 81, p. 41354151.

Jackson, E. D., 1969. Chemical variation in coexisting chromite and olivine in chromite zones of the Stillwater Complex. In Wilson, H. D. B. (Ed.), Magmatic ore deposits, Econ. Geol. Mon., v. 4, p. 41-71.

Loney, R. A., Himmelberg, G. R., and Coleman, R. G., 1971. Structure and petrology of the alpine-type peridotite at Burro Mountain, California, U.S.A., J. Petrol., v. 12, p. 245-309.

MacGregor, I. D., 1974. The system $\mathrm{MgO}-\mathrm{Al}_{2} \mathrm{O}_{3}-\mathrm{SiO}_{2}$ : solubility of $\mathrm{Al}_{2} \mathrm{O}_{3}$ in enstatite for spinel and garnet peridotite compositions, Am. Mineralogist, v. 59, p. $110-$ 119.

Obata, M., 1976. The solubility of $\mathrm{Al}_{2} \mathrm{O}_{3}$ in orthopyroxenes in spinel and plagioclase peridotites and spinel pyroxenite, Am. Mineralogist, v. 61, p. 804-816.

Presnall, D. C., 1976. Alumina content of enstatite as a geobarometer for plagioclase and spinel lherzolites, $\mathrm{Am}$. Mineralogist, v. 61, p. 582-588.

Sigurdsson, H. and Schilling, J.-G., 1976. Spinels in MidAtlantic Ridge basalts: chemistry and occurrence, Earth Planet. Sci. Lett., v. 29, p. 7-20.

Sinton, J. M., 1977. Equilibration history of the basal alpinetype peridotite, Red Mountain, New Zealand, J. Petrol., v. 18 , p. $216-246$.

Wilkinson, J. F. G., Duggan, M. B., Herbert, H. K., and Kalocsai, G. I. Z., 1975. The Salt Lick Creek layered intrusion, east Kimberley region, Western Australia, Contrib. Mineral. Petrol., v. 50, p. 1-23.

Wilshire, H. G. and Jackson, E. D., 1975. Problems in determining mantle geotherms from pyroxene compositions of ultramafic rocks, J. Geol., v. 83, p. 313-329.

Wood, B. J. and Banno, S., 1973. Garnet-orthopyroxene and orthopyroxene-clinopyroxene relationships in simple and complex systems, Contrib. Mineral. Petrol., v. 42, p. 109124. 